\title{
Climate Change Awareness and Perception amongst the Inhabitants of Muscat Governorate, Oman
}

\author{
Ali Said Al Buloshi, Elnazir Ramadan \\ Department of Geography, Sultan Qaboos University, Muscat, Oman \\ Email: alnazir@squ.edu.om
}

Received 5 March 2015; accepted 16 August 2015; published 19 August 2015

Copyright (C) 2015 by authors and Scientific Research Publishing Inc.

This work is licensed under the Creative Commons Attribution International License (CC BY). http://creativecommons.org/licenses/by/4.0/

(c) (i) Open Access

\begin{abstract}
Public awareness and knowledge on climate change constitute essential background to deal with climate change and related problems. Alongside this background, this study assesses the awareness and quality of knowledge regarding climate change in Muscat governorate, Oman. A survey of 350 randomly sampled respondents was conducted using a standard questionnaire. A structured questionnaire was used for data collection. This questionnaire was administered to respondents who were evenly distributed among the six divisions (Wilayat) of Muscat governorate in Oman while descriptive statistics were the main analysis techniques. Results have revealed that public awareness is fairly high despite some limitations on the knowledge on the causes and prevention of climate change. Regression analysis finds that gender, years of education, and income are significant factors that determine the level of awareness. Climate change is an area that is in need of publicity to help the public make informed decisions in its adaptation and mitigation. Results further indicate that most of the respondents have fair general knowledge about the subject.
\end{abstract}

\section{Keywords}

Climate Change, Awareness, Perception, Survey, Sultanate of Oman

\section{Introduction}

Because of its risks climate change is a global concern that attracted the attention of all communities and particularly the coastal ones like the Sultanate of Oman. Risks include increased sea levels due to thermal expansion of the ocean, a higher frequency and intensity of coastal and inland storms, and accelerated erosion. Unfortunately, these zones are also heavily populated and have high rates of urban growth (Dronkers et al., 1990; Wu et 
al., 2002) [1]. The global campaigns for dealing with climate change, including the United Nations Framework Convention on Climate Change and its Kyoto Protocol, have emphasized the significant impacts made by general public and key stakeholders to deal with alleviation of climate change effects. It is quite evident that governments are only responsible for a small amount of greenhouse gas emission, hence they should direct businesses, communities and individuals to modify their practices to help reduce emissions and enhance sustainability (UNPEP2006) [2]. Governments can employ various techniques to encourage people to make substantial changes. Policies and legislation can play a major role in making actions and activities responsible of more gas emission to be inaccessible or of high cost while on the other hand making activities that lower emissions and promote adaptation less expensive. Regulations and standards as well as taxes and subsidies can also be reformed to influence practices (Wu et al., 2002) [3]. Such policies and measures, however, can encounter inertia, passive resistance or active opposition, particularly from those concerning about the imposition of a new coat. Providing information and explanations are therefore vital for generating public and stakeholder support for government policies and regulations. Public outreach can also encourage voluntary changes in behaviours, address the opinions of those who oppose specific actions and help to prepare the younger generation for living in the climate-change world that they will soon inherit (Tikka et al., 2000) [4]. Many stakeholders including governments are working actively to raise awareness. The scale of the change required is of various directions and government contribution, and particularly in the developing world is quite crucial regarding the magnitude of groups that must be influenced. Governments have to encourage local authorities, nongovernmental organizations (NGOs), educators, media, and individuals to play a role. There is considerable research that directed towards investigating public awareness about climate change based on surveys of public opinion. Many scholars have analyzed the issue of climate change in terms of public perception (e.g., Berk and Schulman, 1995 [5]; Leiserowitz, 2005, 2006 [6] [7]; O'Connor et al., 1999 [8]). The results of these studies have revealed that many people misunderstand the science of climate change and, in particular, are confused about the nature, causes and consequences of climate change (Bord et al., 1998 [8]; Dodman, 2009 [9]). Depth of understanding of climate-change issues depends largely on individual characteristics such as educational level, age, gender, occupation and ethnic origin (Aoyagi-Usui et al., 2003; Ester et al., 2003; Aoyagi-Usui, 2008 [10]; Iizuka, 2000 [11]; Sterman, 2011 [12]; Parry, 2007 [13]). Most of these studies have focused on how the public understands the issue of climate change. However, with respect to Arab counties and Gulf region in particular, these studies are so rare, despite the fact that these countries contribute highly in the global phenomena due to their high urbanization nature. The GCC (Gulf Cooperation Council) countries are one of the most urbanized areas in the world, with over 70 percent of the population living in urban areas and with Kuwait and Qatar with almost 100 percent urbanization. Urban expansion in the region has been fuelled by both internal migration and the influx of expatriate workers attracted by the region's economic prosperity and employment opportunities. Climate change is a problem associated with Gulf cities and will exacerbate the vulnerability of cities to natural phenomena (Satterthwaite et al., 2007) [14]. In the case of the Arab Gulf countries, rapid population growth and urbanization are contributing to the vulnerability of cities to climate change (Mustafa, 2005) [15]. The main objective is to assess the public awareness about climate change in Muscat governorate. According to its coastal location, Oman has set great attention to climate change issues. Therefore this study comes as a response to that need. In addition this study highlights the need for more outreach and research about climate change issues that affect communities and looks for effective mechanisms to build resilience and engage the public.

\section{Materials and Methods}

A survey questionnaire designed to evaluate public awareness and Omanis perception of climate change in Muscat governorate, Oman, was administered to 350 randomly selected respondents during November 2014. The respondent was asked to fill out the questionnaire and answer all the questions.The first part of the questionnaire was about general demographic and personal information. In the second part of the questionnaire respondents were asked to assess their knowledge about climate change issues, through answering 18 multiplechoice questions on a variety of climate related issues. The questions concentrate on knowledge and awareness about climate change, causes and impacts of the phenomenon as well as respondents responses. Multiple possible choices were given for each question. The Questionnaires were randomly distributed to the six states (Divisions) of Muscat governorate. Responses were highest in Al Seeb which account for 29.3\%, then followed by 
Muttrah 22.6\% then Buchar 18\%, Al Amarat 14.6\%, Muscat 14\% and last Qurayyat 1.3\% of the sample (Figure 1).

\section{Results and Discussion}

A total of 350 respondents from all the six (Wilayat) divisions of the Muscat governorate were surveyed in this study. Table 1 gives the basic demographic information of the respondents obtained from the survey. With respect to sex, $42 \%$ of the samples were male, while $58 \%$ were female. With regard to age, $82 \%$ of the respondents were between 14 - 25 years old, 7.33\% were between 26 - 35 and $10 \%$ were between 36 - 50. The rest of the respondents were older than 51 years older $(0.67 \%)$. With respect to educational level, $81.3 \%$ of the respondents reported they possess university level education and $14 \%$ achieved secondary level education. The rest of the sample indicated they attended middle school (2\%), primary school (1\%) and $1 \%$ were illiterate. This indicates that the sample has more young and educated respondents. This is also might be justified by the fact that Muscat governorate attracts more immigrant populations from all parts of the Sultanate. It's the economic hub of the country, with many educational and entertainment activities that draw young people to come and live in the city. The first part in the survey is dealing with general knowledge about climate change issues. It has revealed that $96 \%$ of the respondents of the sample agreed that they have some knowledge about the subject while the remaining parts $4 \%$ indicated that they have no idea. Most of the respondents justify this knowledge to various resources, including their observation that climatic conditions have changed. Most of them $86.7 \%$ of the sample assumed that change in climatic condition in exhibited in temperature increase, while only $4.7 \%$ believe that climatic change means to them a drop in temperature degrees. The remaining percentage of $8.7 \%$ explained that they cannot identify any feature of climate change, but they feel that there is some change. When respondents were asked to find out the causes of climate change, most of them relates that to human activities, namely Transport sector, $75 \%$ of the sample, industrial sector, $34 \%$ and energy sector, $23 \%$, while the remaining $18 \%$ percent mentioned that they cannot identify a single cause for the phenomenon. All confirmed that climate change has serious impacts on our lives, $64 \%$ of the sample thinks climate change leads to Natural hazards, including flood risk and the spread of diseases, $18 \%$ percent think it will lead to desertification and drought $16 \%$ to water pollution and $15 \%$ to agricultural productivity decline, while $10 \%$ thinks the tourist destinations on the Omani coasts will be the most to be affected. When respondents were asked to pinpoint who cause climate change on a global scale, $56 \%$ indicated that developed countries are the most responsible, while $21.3 \%$ indicated that developing countries are the most responsible the remaining percent of $22.7 \%$ consider both are responsible (Table 1).

When respondents were asked whether they thinks their government is doing enough with issue of climate change $49.3 \%$ were not sure about the government programs that deal with the subject, $29.3 \%$ consider that the government is not doing enough. While the remaining $21.3 \%$ agreed that the government is doing fine with the subject. With respect to climate change adaptation and mitigation efforts, respondents answer a number of questions that relates to their knowledge of the global mobilization campaign against climate change $77.3 \%$ confirmed their awareness of a global campaign for climate change impact adaptation and mitigation. Respondents have indicated that they get information from different sources as shown in Figure 2.

The figure shows that the most prevalent source of information on climate change is TV channels, whether international where $48 \%$ of the respondent stated that they get their information from these sources or local where $36 \%$ of the sample mentioned out. Then come after educational curriculum where $27 \%$ of the sample

Table 1. Causes of climate change.

\begin{tabular}{|c|c|c|c|c|c|}
\hline \multicolumn{6}{|c|}{ Who Causes Climate Change } \\
\hline & & Frequency & Percent & Valid Percent & Cumulative Percent \\
\hline \multirow{4}{*}{ Valid } & Developed Countries & 84 & 56.0 & 56.0 & 56.0 \\
\hline & Developing Countries & 32 & 21.3 & 21.3 & 77.3 \\
\hline & Both & 34 & 22.7 & 22.7 & 100.0 \\
\hline & Total & 150 & 100.0 & 100.0 & \\
\hline
\end{tabular}




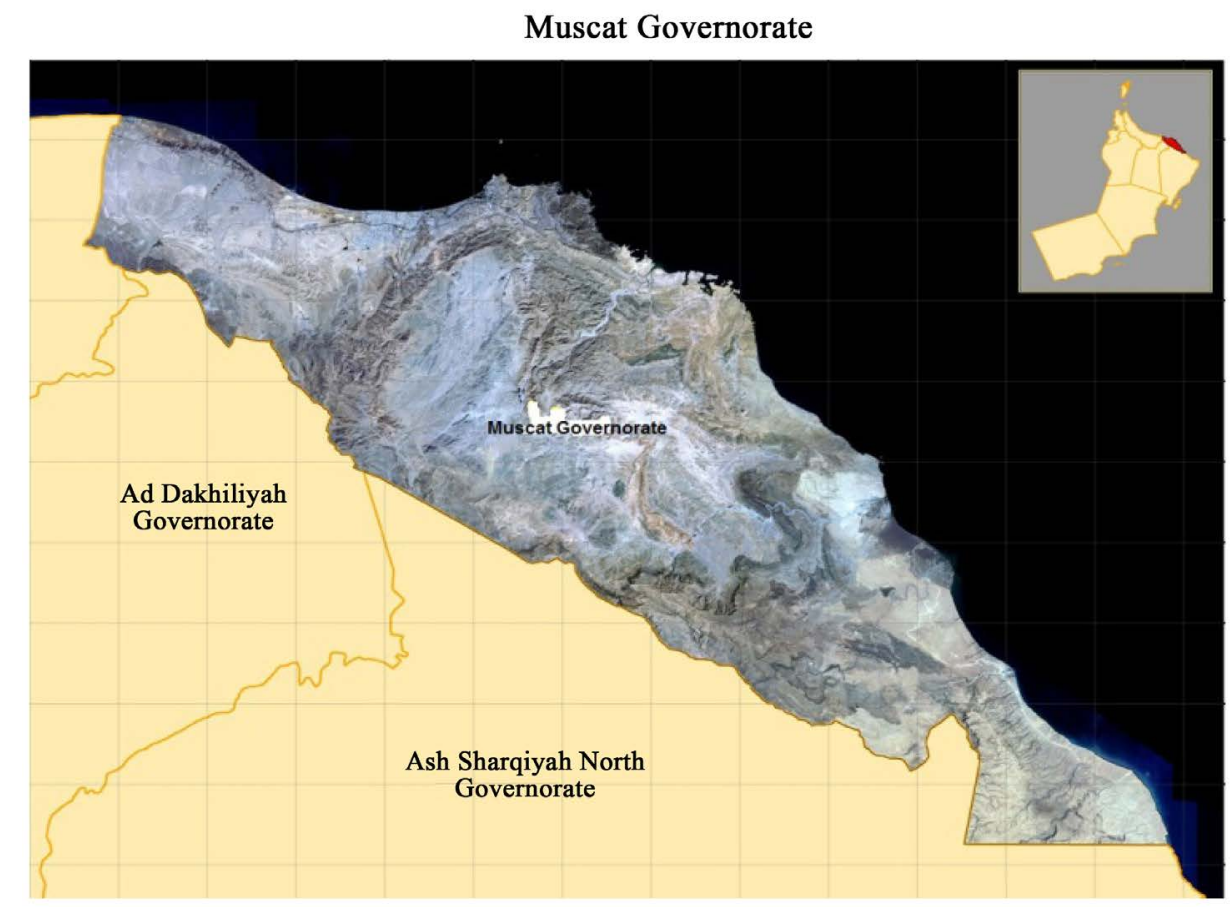

Figure 1. Map of study area.

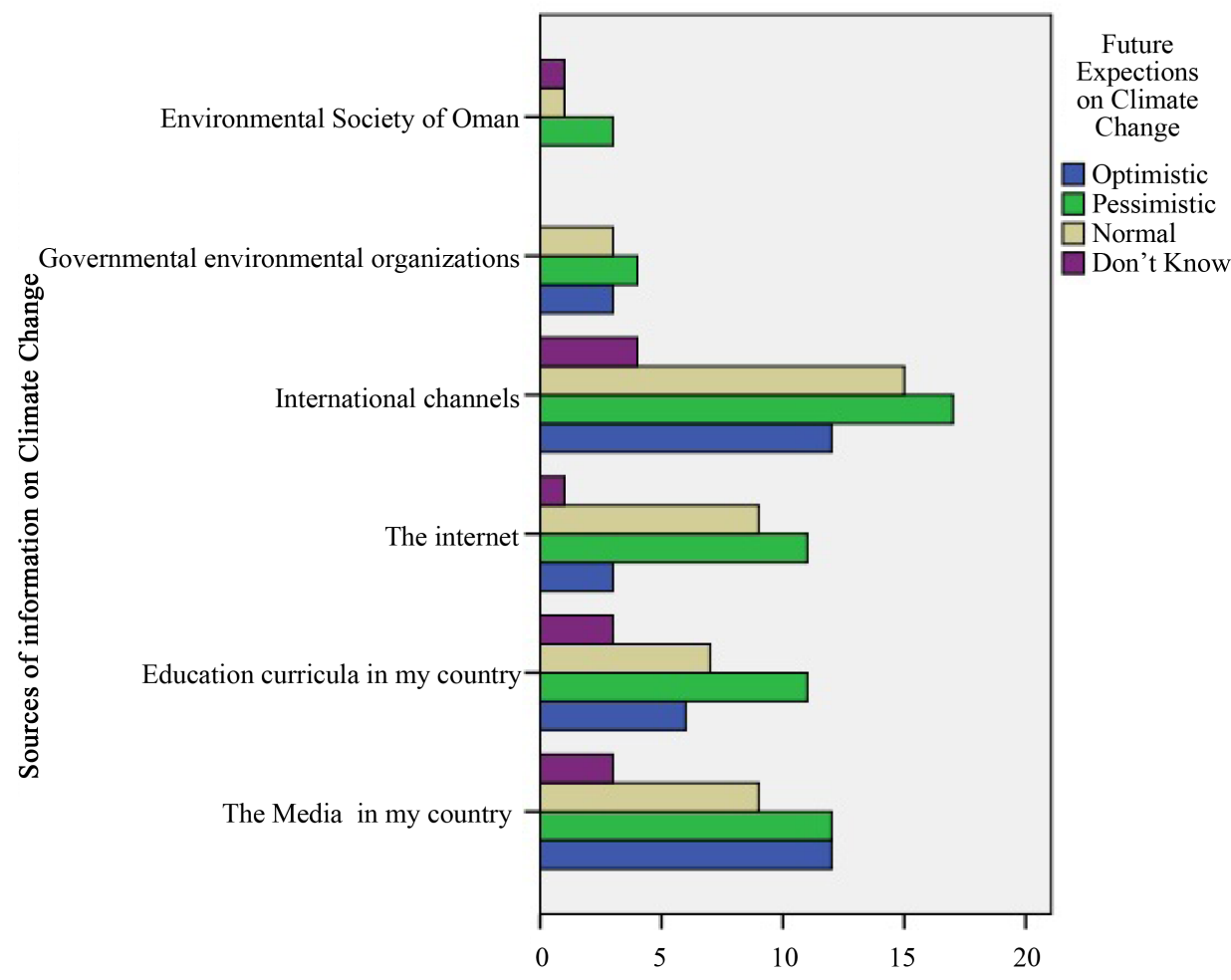

Figure 2. Information on climate change.

have pointed out and the internet and online sources with $24 \%$. At the bottom of the information sources is official government sources and professional civil society institutions. Most of the respondents were pessimistic about the global campaign to fight climatic change and reduce its impacts, they believe that the major players 
are the governments and companies and those stakeholders are doing less in comparison to media, scientific and civil society activists. The respondents also believe that Oman is highly affected by climate change. They considered various signs of these impacts as shown in Table 2.

Figure 3 indicates that climate change impacts of the Sultanate of Oman are evident in several manifestations. $36 \%$ of the sample believed that rainfall fluctuation is the most obvious sign of climate change. While $22 \%$ indicated that the most apparent is indicator is natural disasters. Oman being a coastal region has put the country close to risk associated with climate change like (tropical cyclones). Respondents believe that Oman was one of the most stable countries in terms of natural disasters for years, but recently with the last eight years the country has encountered two cyclones the most disastrous was gone in 2007 which had caused human and property physical losses and the second was Cyclone Phet in 2010, but the latter was less dangerous and damaging. The $14.67 \%$ pointed out that pollution is the most prominent effects of climate change, where the air and water pollution rate has increased in some areas, especially the coastal Batinah coastal line. Due to the relationship between pollution and diseases, $6.67 \%$ of the sample considered that the most prominent effect is the spread of diseases due to the change in temperature and pollution. Health records have revealed the spread of fever diseases and tuberculosis, where the proportion of tuberculosis has increased recently due to moisture and air pollution. The rest of sample which is $8.67 \%$ considered the most likely apparent features of climate change are economic stresses and rising food prices.

The last part of the survey was dealing with assessing whether respondents have an understanding of the idiom (think global, act local) which illustrates that international agreements cannot solve any global environmental problems without concrete actions on the ground. Climate change in this respect is a challenge for the international community as well as for national and local actors everywhere. The respondents were asked whether they ready to get engaged in any activity that help reducing climate change impacts. $92.7 \%$ of the sample

Table 2. Cross tabulation of manifestations of climate change and mitigation and adaptation options.

\begin{tabular}{|c|c|c|c|c|c|c|c|c|c|c|c|}
\hline \multicolumn{12}{|c|}{ Manifestations of Climate Change in Oman*Mitigation and Adaptation of Climate Change Cross tabulation } \\
\hline \multicolumn{12}{|c|}{ Count } \\
\hline & & \multicolumn{9}{|c|}{ Mitigation and Adaptation of Climate Change } & \multirow[b]{2}{*}{ Total } \\
\hline & & $\begin{array}{c}\text { Reducing } \\
\text { energy } \\
\text { consumption }\end{array}$ & $\begin{array}{c}\text { Protection } \\
\text { of low } \\
\text { coastal } \\
\text { areas }\end{array}$ & $\begin{array}{c}\text { Education } \\
\text { and } \\
\text { Awareness } \\
\text { raising }\end{array}$ & $\begin{array}{c}\text { Planning } \\
\text { enforcement }\end{array}$ & $\begin{array}{c}\text { Forest } \\
\text { protection } \\
\text { and } \\
\text { development }\end{array}$ & $\begin{array}{l}\text { Scientific } \\
\text { research }\end{array}$ & $\begin{array}{l}\text { Development } \\
\text { of alternative } \\
\text { crops }\end{array}$ & $\begin{array}{c}\text { Law and } \\
\text { legal } \\
\text { framework } \\
\text { enforcement }\end{array}$ & Others & \\
\hline \multirow{7}{*}{$\begin{array}{c}\text { Manifestations } \\
\text { of Climate } \\
\text { Change in } \\
\text { Oman }\end{array}$} & $\begin{array}{l}\text { Increase in } \\
\text { temperature } \\
\text { and decrease } \\
\text { in rainfall }\end{array}$ & 9 & 7 & 7 & 10 & 6 & 7 & 2 & 6 & 0 & 54 \\
\hline & $\begin{array}{c}\text { Rising } \\
\text { food prices }\end{array}$ & 3 & 1 & 0 & 3 & 0 & 2 & 1 & 3 & 0 & 13 \\
\hline & $\begin{array}{l}\text { Increased } \\
\text { pollution } \\
\text { and } \\
\text { contaminants } \\
\text { ratio }\end{array}$ & 2 & 2 & 0 & 7 & 4 & 1 & 0 & 4 & 2 & 22 \\
\hline & $\begin{array}{l}\text { Coastal } \\
\text { erosion and } \\
\text { rise of } \\
\text { sea level }\end{array}$ & 1 & 1 & 0 & 4 & 2 & 0 & 1 & 0 & 0 & 9 \\
\hline & $\begin{array}{c}\text { Frequency of } \\
\text { natural } \\
\text { hazards }\end{array}$ & 5 & 1 & 4 & 4 & 2 & 5 & 1 & 6 & 5 & 33 \\
\hline & $\begin{array}{c}\text { Decrease of } \\
\text { flora and fauna }\end{array}$ & 0 & 0 & 2 & 1 & 1 & 2 & 0 & 1 & 2 & 9 \\
\hline & $\begin{array}{l}\text { Increase of } \\
\text { diseases }\end{array}$ & 1 & 2 & 1 & 2 & 1 & 0 & 3 & 0 & 0 & 10 \\
\hline \multicolumn{2}{|c|}{ Total } & 21 & 14 & 14 & 31 & 16 & 17 & 8 & 20 & 9 & 150 \\
\hline
\end{tabular}




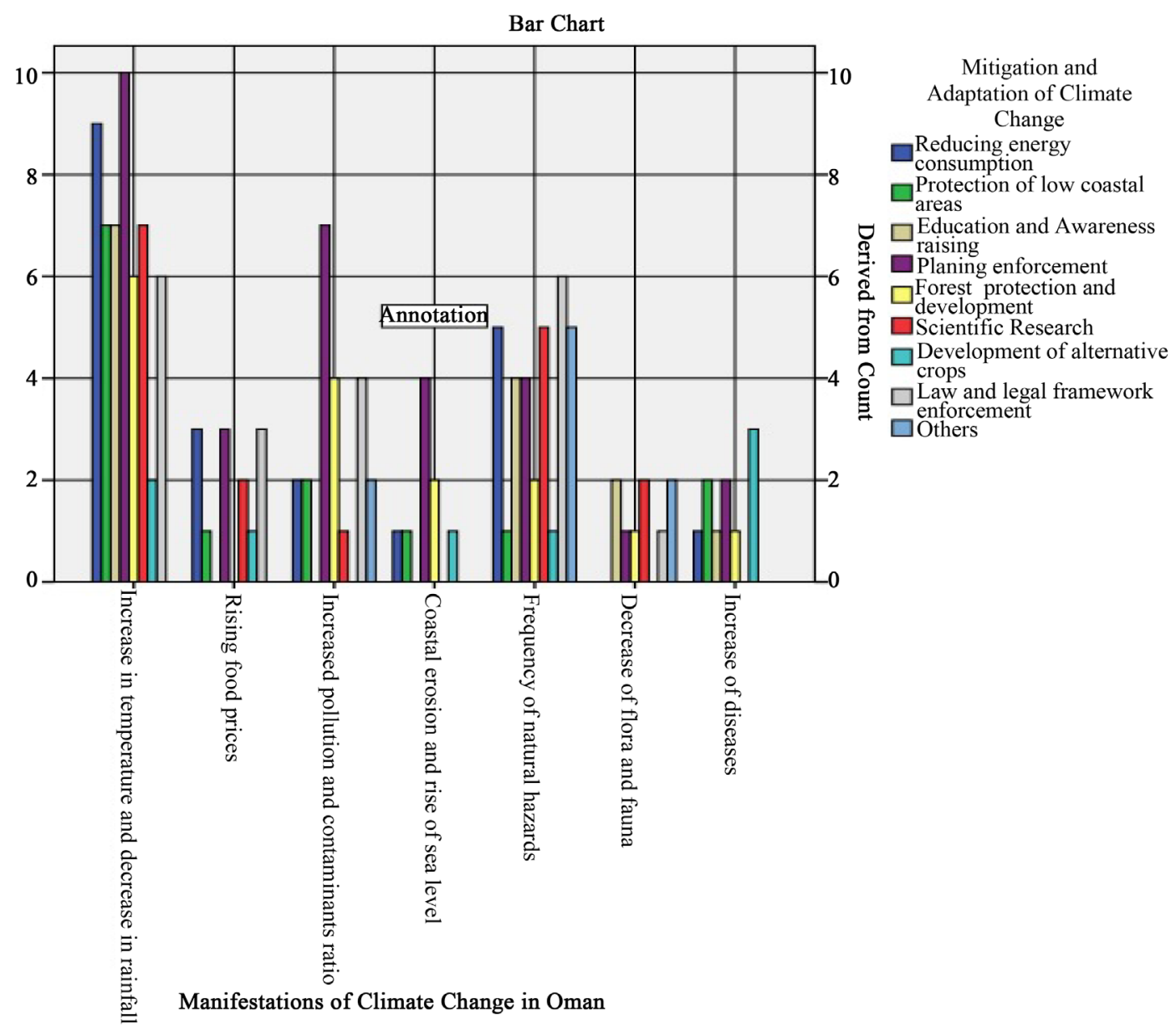

Figure 3. Manifestations of climate change in Oman.

declared their readiness to contribute to reduce the causes of this phenomenon, commensurate with their abilities, while the remaining $7.3 \%$ did not show any willingness to participate in any effort to combat the phenomenon. They likely consider that the problem is better solved at official level and through government intervention not individuals work Most of the respondents, $70 \%$ of the sample considered the reduction of greenhouse gas emissions is the most serious solution to reduce the causes of climate change. They also believe that the high emission sector in Oman is transport sector in compare to industrial sector, which not so developed in Oman and contribute less, while $25.3 \%$ disagree with this opinion as they believe that Oman is contributing less to climate change in comparison to other countries. The remaining $4.7 \%$ of the sample believe that there other reasons not necessary the emissions.

\section{Conclusion}

The present study has tried to investigate public local awareness about climate change in a local situation and in mind it is the international climate change negotiations which are running between all countries, whether developing or developed, to reach an understanding in the best ways to deal with this global environmental issue. Local opinions of people are shaped by various characteristics, yet they represent solid base for further actions. The results reveal that public awareness about climate change in Muscat governorate is fairly high; this conclusion might be attributed to the fact that Muscat residents are most enlightened and educated segment of the Omani people. Another fact is that the study sample contains more young and educational respondents. However, the public was more knowledgeable about general issues that are covered in the media as well as local problems associated with climate change like natural disasters. The Sultanate of Oman has witnessed some disastrous cyclones like Gonu which stroke the country in 2007. The cyclone has brought the attention of climate change and 
its association with natural disasters to everyone in the country. It has helped raise the awareness about climate change in addition. The present study is significant as it addresses public awareness and perception about climate change in the Sultanate of Oman. Results obtained from the survey are quite vital not only for assessing the present status of public awareness about climate change in Oman, but also for improving insight on environmental awareness in general. In addition, the results of the paper are hoped to be a valuable resource to those involved with environmental awareness studies, especially in developing countries where such studies in this regard are inadequate. Further, the study can provide baseline information to decision makers with respect to the environmental awareness in Oman. Accordingly, concerned stakeholders and decision makers can use the public's opinions gained from this study as a guide for developing strategies and policies for effective adaption and mitigation processes. Moreover, the study might serve as background to track state funded patterns with respect to natural mindfulness matters later on. Past investigations accessible in the open written works demonstrated that climate change consciousness might have been connected with diverse demographic variables such sex, age, and education level. However, various investigations showed conflicting outcomes about these variables. The study goes the direction supporting the argument which emphasizes the association between demographic variables and climate change awareness in Oman.

\section{References}

[1] Dronkers, J., Gilbert, J.T.E., Butler, L.W., Carey, J.J., Campbell, J., James, E., McKenzie, C., Misdorp, R., Quin, N., Ries, K.L., Schroder, P.C., Spradley, J.R., Titus, J.G., Vallianos, L. and von Dadelszen, J. (1990) Strategies for Adaptation to Sea Level Rise. Report of the IPCC Coastal Zone Management Subgroup: Intergovernmental Panel on Climate Change, Geneva.

[2] United Nations Environment Programme’s Division of Environmental Law and Conventions (2006) Raising Awareness of Climate Change. A Handbook for Government Focal Points.

[3] Wu, S.-Y., Yarnal, B. and Fisher, A. (2002) Vulnerability of Coastal Communities to Sea-Level Rise: A Case Study of Cape May County, New Jersey, USA. Climate Research, 22, 255-270. http://dx.doi.org/10.3354/cr022255

[4] Tikka, P.M., Kuitunen, M.T. and Tynys, S.M. (2000) Effects of Educational Background on Students’ Attitudes, Activity Levels, and Knowledge Concerning the Environment. Journal of Environmental Education, 31, 12-19. http://dx.doi.org/10.1080/00958960009598640

[5] Berk, R.A. and Schulman, D. (1995) Public Perceptions of Global Warming. Climatic Change, 29, 1-33. http://dx.doi.org/10.1007/BF01091637

[6] Leiserowitz, A. (2006) Climate Change Risk Perception and Policy Preferences: The Role of Affect, Imagery, and Values. Climatic Change, 77, 45-72. http://dx.doi.org/10.1007/s10584-006-9059-9

[7] Leiserowitz, A., Kates, R.W. and Parris, T.M. (2005) Do Global Attitudes and Behaviours Support Sustainable Development? Environment, 47, 22-38. http://dx.doi.org/10.3200/ENVT.47.9.22-38

[8] Bord, R.J., Fisher, A. and O’Connor, R.E. (1998) Public Perceptions of Global Warming: United States and International Perspectives. Climate Research, 11, 75-84. http://dx.doi.org/10.3354/cr011075

[9] Dodman, D. (2009) Blaming Cities for Climate Change? An Analysis of Urban Greenhouse Gas Emissions Inventories. Environment and Urbanization, 21,185-201. http://dx.doi.org/10.1177/0956247809103016

[10] Aoyagi-Usui, M., Vinken, H. and Kuribayashi, A. (2003) Pro-Environmental Attitudes and Behaviors: An International Comparison. Human Ecology Review, 10, 23-31.

[11] Iizuka, M. (2000) Role of Environmental Awareness in Achieving Sustainable Development. Enhancement of Citizen's Awareness in Formulation of Pollution Control Policies in Major Latin American Cities, Environment and Human Settlements Division of ECLAC.

[12] Sterman, J.D. (2011) Communicating Climate Change Risks in a Skeptical World. Climatic Change, 108, 811-826. http://dx.doi.org/10.1007/s10584-011-0189-3

[13] Parry, M.L. (2007) Climate Change 2007: Impacts Adaptation and Vulnerability: Working Group II Contribution to the Fourth Assessment Report of the IPCC Intergovernmental Panel on Climate Change. Cambridge University Press, Cambridge.

[14] Satterthwaite, D., Huq, S., Pelling, M., Reid, H. and Romero Lankao, P. (2007) Adapting to Climate Change in Urban Areas: The Possibilities and Constraints in Low- and Middle-Income Nations. International Institute for Environment and Development (IIED), London.

[15] Khogali, M. (2005) Health and Disease in a Changing Arab World 2000/2025/2050: Global, Environmental, and Climate Change and Emerging Diseases. Ethnicity and Disease, 15, S1-74-75. 